\title{
Frequencies of candidate genes and associations with carcass and meat traits in Nellore and crossbred cattle
}

\author{
Victor Augusto Domingos Dias ${ }^{(1)}$, Rogério Abdallah Curi(2), Guilherme Luis Pereira(1), \\ Jéssica Moraes Malheiros ${ }^{(1)}$, Rafael Espigolan ${ }^{(1)}$, Lúcia Galvão de Albuquerque ${ }^{(1)}$, \\ Luis Artur Loyola Chardulo(2) and Henrique Nunes de Oliveira ${ }^{(1)}$
}

\begin{abstract}
(1)Universidade Estadual Paulista Júlio de Mesquita Filho (Unesp), Faculdade de Ciências Agrárias e Veterinárias, Campus de Jaboticabal, Via de Acesso Prof. Paulo Donato Castellane, s/no, CEP 14884-900 Jaboticabal, SP, Brazil. E-mail: victordiaszootecnista@gmail.com, guipicoia@hotmail.com, jessicamalheiros@yahoo.com.br, espigolan@yahoo.com.br, Igalb@fcav.unesp.br, holiveira@fcav.unesp.br (2)Unesp, Faculdade de Medicina Veterinária e Zootecnia, Departamento de Melhoramento e Nutrição Animal, Campus de Botucatu, Fazenda Experimental Lageado, CEP 18618-970 Botucatu, SP, Brazil. E-mail: rogcuri@fmvz.unesp.br, chardulo@fmvz.unesp.br
\end{abstract}

Abstract - The objective of this work was to estimate allelic frequencies of the polymorphisms $I G F 2 / M b o$ II $(\mathrm{G}>\mathrm{T})$ of the insulin-like growth factor $2(I G F 2)$ gene, DQ499531.1:g.134A $>$ T of the pro-melanin-concentrating hormone $(P M C H)$ gene, and DQ667048.1:g.3290G > T of the RAR-related orphan receptor C (RORC) gene in beef cattle of different genetic groups, and to evaluate the associations between these polymorphisms and traits related to carcass composition and meat quality. Data on carcass and meat quality of 499 animals was used: of 313 Nellore (Bos indicus) and of 186 Nellore crossed with different taurine (Bos taurus) breeds. For the IGF2/MboII polymorphism, the frequencies found for the $\mathrm{G}$ allele were 0.231 and 0.631 for Nellore and crossed breeds, respectively. For the DQ499531.1:g.134A > T polymorphism, the allelic frequencies of A were 0.850 for Nellore and 0.905 for crossed breeds. For the DQ667048.1:g.3290G > T polymorphism, the allelic frequencies of $\mathrm{G}$ were 0.797 and 0.460 for Nellore and crossed breeds, respectively. The evaluated single nucleotide polymorphisms (SNPs) are not significantly associated with carcass and meat traits (rib eye area, back fat thickness, shear force, total lipids, and myofibrillar fragmentation index), suggesting little utility of the analyzed polymorphisms of the IGF2, $P M H C$, and $R O R C$ genes as selection markers in the studied cattle populations.

Index terms: Bos indicus, beef cattle, beef quality, polymorphism.

\section{Frequências de genes candidatos e associações com características de carcaça e da carne em bovinos da raça Nelore e cruzados}

Resumo - O objetivo deste trabalho foi estimar as frequências alélicas dos polimorfismos IGF2/MboII (G > T) do gene "insulin-like growth fator 2"(IGF2), DQ499531.1:g.134A > T do gene "pro-melanin-concentrating hormone" $(P M C H)$ e DQ667048.1:g.3290G> T do gene "RAR-related orphan receptor C" (RORC) em bovinos de corte de diferentes grupos genéticos, e avaliar a ocorrência de associações entre esses polimorfismos e características relacionadas à composição da carcaça e à qualidade de carne. Foram utilizados dados de carcaça e qualidade de carne de 499 animais: 313 da raça Nelore (Bos indicus) e 186 provenientes de seus cruzamentos com raças taurinas (Bos taurus). Para o polimorfismo IGF2/MboII, as frequências encontradas para o alelo G foram 0,231 e 0,631 para Nelore e cruzados, respectivamente. Para o polimorfismo DQ499531.1:g.-134A > T, as frequências alélicas de A foram 0,850 para Nelore e 0,905 para cruzados. Para o polimorfismo DQ667048.1:g.3290G > T, as frequências alélicas de $\mathrm{G}$ foram 0,797 e 0,460 para Nelore e cruzados, respectivamente. Os polimorfismos de nucleotídeo único (SNPs) avaliados não se relacionam significativamente com as características de carcaça e carne (área de olho de lombo, espessura de gordura subcutânea, força de cisalhamento, lipídeos totais e índice de fragmentação miofibrilar), o que sugere pouca utilidade dos polimorfismos analisados dos genes $I G F 2, P M H C$ e $R O R C$ como marcadores de seleção nas populações bovinas estudadas.

Termos para indexação: Bos indicus, bovinos de corte, qualidade da carne, polimorfismo.

\section{Introduction}

Candidate genes for traits of interest are identified based on physiology, differential gene expression, and genome scans (Zhu \& Zhao, 2007). Most production traits in cattle are governed by a large number of genes, i.e., are quantitative. Therefore, the identification of quantitative trait loci (QTL) in the genome of these 
animals has been the recent focus of genome-wide association studies (GWAS), which are carried out by the genotyping of hundreds of thousands of single nucleotide polymorphisms (SNPs) using high-density chips (Hayes \& Goddard, 2010). However, the existence of major genes responsible for most of the variation in a trait is also possible (Zhu \& Zhao, 2007).

Aiming to identify major genes, several studies have analyzed polymorphisms of functional and positional candidate genes to assist selection by markers. According to these studies, insulin-like growth factor 2 (IGF2), pro-melanin-concentrating hormone $(P M C H)$, and RAR-related orphan receptor C (RORC) are candidate genes that are possibly associated with traits of interest in livestock (Flisikowski et al., 2005; Barendse et al., 2006; Helgeson \& Schmutz, 2008).

The protein encoded by $I G F 2$ is a fetal-growth and differentiation factor that has an important role in muscle growth, as well as in the proliferation and differentiation of myoblasts (Flisikowski et al., 2005). In a study performed by Nezer et al. (1999), a QTL with stronger effects on muscle mass and fat deposition in the carcass was mapped to the region of the IGF2 locus in swine. PMHC encodes, among others, the melanin-concentrating hormone $(\mathrm{MCH})$, and, in mice, the overexpression of the $\mathrm{MCH}$ has been associated with obesity, resistance to insulin, and reduced metabolism (Ludwig et al., 2001; Ito et al., 2003). The QTL responsible for affecting fat deposition in the carcass have been identified in overlapping regions of the bovine chromosome 3. RORC, besides being located within the confidence interval in which those QTL have been mapped (Barendse et al., 2006), is highly expressed in mammalian skeletal muscle (Hirose et al., 1994).

Polymorphisms of the IGF2, PMCH, and RORC genes were associated with carcass and meat traits in Bos taurus cattle (Schmutz \& Goodall, 2005; Barendse et al., 2006; Sherman et al., 2008; Helgeson \& Schmutz, 2008; Zwierzchowski et al., 2010; Sevane et al., 2011). However, before using molecular markers that have been identified for other populations, it is critical to study their effects on traits of interest in different breeds and environments (Allais et al., 2011). According to Casas et al. (2005), the results obtained for the association between molecular markers and traits in $B$. taurus are not immediately applicable to Bos indicus, and, therefore, need to be widely studied. Moreover, it is possible that the polymorphisms that occur and are associated with interesting traits in $B$. taurus do not necessarily occur in B. indicus (Casas et al., 2005; Curi et al., 2009). This shows that more studies are necessary regarding the polymorphisms of the IGF2, PMCH, and RORC genes in B. indicus, especially in Nellore.

The objective of this work was to estimate allelic frequencies of the polymorphisms IGF2/MboII $(\mathrm{G}>\mathrm{T})$ of the insulin-like growth factor 2 (IGF2) gene, DQ499531.1:g.134A $>\mathrm{T}$ of the pro-melanin-concentrating hormone $(P M C H)$ gene, and DQ667048.1:g.3290G > T of the RAR-related orphan receptor $\mathrm{C}(R O R C)$ gene in beef cattle of different genetic groups, and to evaluate the associations between these polymorphisms and traits related to carcass composition and meat quality.

\section{Materials and Methods}

Data on the meat and carcass quality of 499 Nellore and Nellore $\times$ taurine cattle breeds were used. From this total of animals, 199 were male Nellore, younger than 2 years of age, which had been kept in confinement in farms that are part of the Delta $G$ connection breeding program (Conexão Delta $G, 2016)$. On these farms, animals that are born less than 3 months apart are grouped and subjected to the same conditions until weaning. Subsequently, new groups are formed and subjected to the same conditions until the animals are yearlings, when they are used for breeding or sent to confinement until slaughter.

Another 256 animals were taken from seven commercial cattle farms in the state of São Paulo, Brazil, being slaughtered in 2003, 2005, 2006, and 2007 in the experimental confinement section of Faculdade de Ciências Agrárias e Veterinárias of Universidade Estadual Paulista Júlio de Mesquita Filho, in the municipality of Botucatu, in the state of São Paulo, Brazil, under the "super-precocious" production system (Silveira et al., 2004). Of these animals, 114 belonged to the Nellore $(B$. indicus) breed, 67 were Angus $\times$ Nellore crossbred $(1 / 2$ B. taurus $+1 / 2$ B. indicus $), 41$ were Canchim (5/8 Charolais $+3 / 8 B$. indicus $), 19$ were triple-cross Brangus (9/16 B. taurus $+7 / 16$ B. indicus $)$, and 15 were triple-cross Brown Swiss (3/4 B. taurus + $1 / 4$ B. indicus).

The evaluated sample was completed with another 44 animals from crosses between Rubia Galega (B. taurus) and Nellore females (Rubia Galega $\times$ 
Nellore: $1 / 2$ B. taurus $+1 / 2$ B. indicus), which were produced in a semi-intensive breeding system in 2006.

Of the 300 studied animals, excluding those from the Delta $\mathrm{G}$ connection, 32 were female and 268 were male, all of which had been slaughtered between the ages of 15 and 19 months.

After slaughter, which was performed in commercial refrigerators according to the norms stipulated for humanitarian animal slaughter (Ludtke et al., 2012), the carcasses were identified and refrigerated for 24 hours. After refrigeration, two samples including bone, with an approximate thickness of $2.54 \mathrm{~cm}$, were harvested from the longissimus thoracis muscle, between the eleventh and thirteenth ribs in the cranial left-half carcass of each animal. The samples were vacuum packed and frozen. One sample harvested between the twelfth and thirteenth ribs was used for measurements of the ribeye area (REA) and back fat thickness (BT), and for the performance of the shear force (SF) test, using a Warner Bratzler shear machine (G-R Manufacturing Company, Manhattan, KS, USA). The second sample harvested between the eleventh and twelfth ribs was used for chemical analyses of the meat, including total lipids (TL) and the myofibrillar fragmentation index (MFI), as well as for the extraction of genomic DNA. REA was measured using the point-centered quarter method (United States Department of Agriculture, 2000), whereas BT, expressed in millimeters, was measured with a caliper rule. The remaining phenotypic parameters, TL, MFI, and SF, were determined in the laboratory following the methods described by Bligh \& Dyer (1959), Culler et al. (1978), and Wheeler et al. (1995), respectively. DNA extraction was performed by digestion with protease $\mathrm{K}$ and precipitation with $\mathrm{NaCl}$ and alcohol, considered a non-phenolic method (Green \& Sambroock, 2012).

Genotyping of the polymorphisms was performed using the polymerase chain reaction-restriction fragment length polymorphism (PCR-RFLP) technique (Maeda et al., 1989). To identify the $G$ and $\mathrm{T}$ alleles of the IGF2/MboII polymorphism of $I G F 2$, a 407-base pair (bp) fragment, corresponding to a region located on exon 6 , was amplified and digested with the MboII restriction enzyme, by the method outlined in Flisikowski et al. (2005). The A and T alleles of the DQ499531.1:g.134A > T SNP, located in the (5') regulatory region of $P M C H$ were identified by the amplification of a 424-bp fragment and digested with the TaiI enzyme, as in Helgeson \& Schmutz
(2008). In the evaluation of the $\mathrm{G}$ and $\mathrm{T}$ alleles of the DQ667048.1:g.3290G > T SNP of RORC, a 201-bp fragment located on exon 6 was amplified and digested with the $M n 1$ I enzyme, as described by Kaneda et al. (2011). After the digestion of the amplified products, the DNA fragments were separated using 3\% agarose gel for $I G F 2$ and $R O R C$, and $3.5 \%$ agarose gel for $P M C H$, in a horizontal electrophoresis system. A 100-bp ladder was loaded into each gel to facilitate the estimation of the lengths of the amplified and digested fragments. The genotypes of the individuals were determined for each polymorphism, by analyzing the length of the fragments in bp.

After the identification of the genotypes according to the electrophoresis profile, the allelic and genotypic frequencies were calculated for each of the polymorphisms according to Weir (1996). Any significant differences in the allelic frequencies within the genetic groups were determined by a comprehensive study of contingency tables (Curi \& Moraes, 1981).

The allele substitution effect of the analyzed polymorphisms on the traits of interest was estimated through regression of the number of $T$ alleles, using the GLM tool in the SAS software (SAS Institute Inc., Cary, NC, USA). The following equation was applied: $\mathrm{Y}_{\mathrm{ijk}}=\mu+\mathrm{CG}_{\mathrm{i}}+\mathrm{b}_{1} \times \mathrm{n}_{\mathrm{jk}}+\mathrm{b}_{2} \times \mathrm{IA}_{\mathrm{j}}+\varepsilon_{\mathrm{ijk}}$, in which: $\mathrm{Y}_{\mathrm{ijk}}$ is the trait of interest; $\mu$ is the average; $\mathrm{CG}_{\mathrm{i}}$ is the fixed effect of the contemporary group $i$; $b_{1}$ is the coefficient of regression; $n_{\mathrm{jk}}$ is the effect of the $\mathrm{k}$ allele of each polymorphism; $b_{2}$ is the coefficient of regression for the covariable age at the time of slaughter; $\mathrm{IA}_{\mathrm{j}}$ is the age at the time of slaughter; and $\varepsilon_{\mathrm{ijk}}$ is the random error. The contemporary groups were composed of animals belonging to the same genetic group, gender, confinement year, and farm of origin. The bull effect was not included in the linear model, since the number of genotyped animals that were progeny of the same male was too small. Therefore, because of the high number of genotyped progenies from the same bull parents, the chance of a mix-up between genotype effect and bull effect on the evaluated traits was diluted. The correction of hypothesis testing for multiple comparisons was performed with the Bonferroni method (Bonferroni, 1936).

\section{Results and Discussion}

The $\mathrm{G}$ and $\mathrm{T}$ alleles were detected in the analyses of the $I G F 2 / M b o I I(G>T)$ polymorphism of $I G F 2$, 
in all genetic groups (Table 1). Within the Nellore and Angus $\times$ Nellore groups, the T allele was found to have a higher frequency. The opposite trend was observed in the Rubia Galega $\times$ Nellore and triple-cross Brangus groups, which presented a higher G-allele frequency. There was a higher frequency of the $\mathrm{T}$ allele in the Nellore and Angus $\times$ Nellore groups. In addition, three genotypes were observed in the various genetic groups, except in the Rubia Galega $\times$ Nellore and triple-cross Brown Swiss groups, which did not present individuals with the TT genotype.

The allelic distributions for the IGF2/MboII polymorphism observed in the present study were 0.565 and 0.435 for the $\mathrm{G}$ and $\mathrm{T}$ alleles, respectively. These results contradict those presented by Flisikowski et al. (2005), who evaluated the following bovine breeds: Friesian, Charolais, Limousin, Aberdeen Angus, Hereford, Simmental, Brown Swiss (B. taurus), and another breed comprising $B$. indicus animals from Sri Lanka. For $B$. indicus animals, the authors observed a lower frequency for $\mathrm{G}(0.280)$ than for $\mathrm{T}(0.720)$; however, considering only the animals of the Nellore (B. indicus) group, the obtained frequencies are similar to those of the present study. Flisikowski et al. (2005) also reported that the $G$ allele was found only in B. taurus animals. This justifies the results of the present study, which shows a higher frequency of the $\mathrm{G}$ allele in the crossbred groups.

The association analyses between the IGF2/MboII $(\mathrm{G}>\mathrm{T})$ polymorphism and the evaluated traits showed no significant relationship $(\mathrm{p}>0.05)$ between the polymorphism and the traits associated with carcass

Table 1. Allelic and genotypic frequencies of the $I G F 2 /$ $M b o$ II polymorphism of $I G F 2$ in various genetic groups and in the total animal sample ${ }^{(1)}$.

\begin{tabular}{lcccccc}
\hline Genetic group & \multicolumn{2}{c}{ Allelic frequency } & & \multicolumn{3}{c}{ Genotypic frequency } \\
\cline { 2 - 3 } \cline { 6 - 7 } & $\mathrm{G}$ & $\mathrm{T}$ & & GG & GT & TT \\
\hline Nellore (313) & $0.231 \mathrm{Bb}$ & $0.769 \mathrm{Aa}$ & & 0.087 & 0.287 & 0.626 \\
Angus $\times$ Nellore (67) & $0.340 \mathrm{Bb}$ & $0.660 \mathrm{Aa}$ & & 0.100 & 0.480 & 0.420 \\
Rubia Galega $\times$ Nellore (44) & $0.712 \mathrm{Aa}$ & $0.288 \mathrm{Bb}$ & & 0.424 & 0.576 & 0.000 \\
Canchim (41) & $0.604 \mathrm{Aa}$ & $0.396 \mathrm{Ba}$ & & 0.542 & 0.125 & 0.333 \\
Triple-cross Brangus (19) & $0.875 \mathrm{Aa}$ & $0.125 \mathrm{Bb}$ & & 0.833 & 0.083 & 0.083 \\
Triple-cross Brown Swiss (15) & $0.625 \mathrm{Aa}$ & $0.375 \mathrm{Ba}$ & 0.250 & 0.750 & 0.000 \\
\hline Total (499) & 0.565 & 0.435 & 0.373 & 0.383 & 0.244 \\
\hline
\end{tabular}

${ }^{(1)}$ Means followed by equal letters, uppercase between genetic groups and lowercase within genetic groups, do not differ by the comprehensive study of contingency tables (Curi \& Moraes, 1981), at 5\% probability. ${ }^{(2)}$ The number of animals in each genetic group is shown in parentheses. composition and meat quality (REA, BT, SF, MFI, and TL). Even though a nominal $\mathrm{p}$ value of 0.0082 was observed for BT (Table 2), this value was no longer significant after the Bonferroni correction test, which was performed to maintain the error rate of the statistical tests.

The $I G F 2 / M b o I I(G>T)$ polymorphism of $I G F 2$, identified in the bovine chromosome 29, results from the substitution of the $G$ nucleotide by $T$ in exon 6 (Flisikowski et al., 2005). According to these authors, the comparison of bovine $I G F 2$ with that of humans suggests that this SNP is located at a differentially methylated region (DMR) 2 - a region rich in cytosine-phosphate-guanine $(\mathrm{CpG})$ islands with variable methylation states -, with the potential to alter gene expression. However, there are no reports in the literature regarding association studies between this polymorphism and traits of interest in cattle. Other polymorphisms have been described for bovine $I G F 2$, and a few studies have shown a direct association between them and carcass and meat traits (Schmutz \& Goodall, 2005; Sherman et al., 2008; Zwierzchowski et al., 2010).

For the DQ499531.1:g.134A > T polymorphism of $P M C H$, the $\mathrm{A}$ and $\mathrm{T}$ alleles were found in the studied

Table 2. Effects of substituting the $\mathrm{G}$ allele by $\mathrm{T}$ in the $I G F 2 / M b o I I$ polymorphism of $I G F 2$, the A allele by $\mathrm{T}$ in the DQ499531.1:g.134A > T polymorphism of $P M C H$, and the $\mathrm{G}$ allele by $\mathrm{T}$ in the DQ667048.1:g.3290G > T polymorphism of $R O R C(\alpha)$ on ribeye area (REA), back fat thickness (BT), total lipids (TL), shear force (SF), and myofibrillar fragmentation index (MFI) ${ }^{(1)}$.

\begin{tabular}{lccccc}
\hline Statistics & $\begin{array}{c}\text { REA } \\
\left(\mathrm{cm}^{2}\right)\end{array}$ & $\begin{array}{c}\text { BT } \\
(\mathrm{mm})\end{array}$ & $\begin{array}{c}\text { TL } \\
(\%)\end{array}$ & $\begin{array}{c}\text { SF } \\
\left(\mathrm{kgf} \mathrm{cm}^{-2}\right)\end{array}$ & MFI \\
\hline \multicolumn{5}{c}{$I G F 2 / \mathrm{MboII}$ polymorphism } \\
$\alpha$ & -0.5164 & 0.5219 & -0.0083 & -0.0267 & -2.5197 \\
$\mathrm{SE}$ & 0.6724 & 0.1965 & 0.0553 & 0.0701 & 1.2352 \\
$\mathrm{p}$ & 0.4430 & 0.0082 & 0.8803 & 0.7039 & 0.0421 \\
$\mathrm{p}^{2}$ & 1.000 & 0.123 & 1.000 & 1.000 & 0.6315 \\
\hline \multicolumn{5}{c}{ DQ499531.1:g.134A $>$ T polymorphism } \\
$\alpha$ & -0.0836 & -0.2083 & 0.0580 & -0.1132 & 0.9873 \\
$\mathrm{SE}$ & 0.6697 & 0.1881 & 0.0619 & 0.0684 & 1.2737 \\
$\mathrm{p}$ & 0.9007 & 0.2687 & 0.3493 & 0.0984 & 0.4386 \\
$\mathrm{p}^{2}$ & 1.000 & 1.000 & 1.000 & 1.000 & 1.000 \\
\hline \multicolumn{5}{c}{$\mathrm{DQ667048.1:g.3290G} \mathrm{>} \mathrm{T} \mathrm{polymorphism}$} \\
$\alpha$ & -0.4544 & 0.1715 & -0.0702 & -0.1502 & 2.3162 \\
$\mathrm{SE}$ & 0.6937 & 0.1950 & 0.0641 & 0.0707 & 1.3146 \\
$\mathrm{p}$ & 0.5128 & 0.3796 & 0.2740 & 0.0343 & 0.0788 \\
$\mathrm{p}^{2}$ & 1.000 & 1.000 & 1.000 & 0.5145 & 1.000 \\
\hline
\end{tabular}

${ }^{(1)} \mathrm{SE}$, standard error; $\mathrm{p}, \mathrm{p}$-value; and $\mathrm{p}^{2}$, $\mathrm{p}$-value after Bonferroni correction. 
animals (Table 3 ). The A allele was close to fixation in the Angus $\times$ Nellore group. In the other groups, both alleles were observed, and A was more frequent than $\mathrm{T}$. The comparison among the genetic groups showed no significant differences in allelic frequencies. The TT genotype was present only in the Nellore group, whereas the AA genotype was more prevalent than AT and TT.

In the present study, the allelic distributions observed for the DQ499531.1:g.134A > T polymorphism were 0.896 and 0.104 for the $\mathrm{A}$ and $\mathrm{T}$ alleles, respectively. In B. taurus, Helgeson \& Schmutz (2008) found the following frequencies for the $\mathrm{A}$ and $\mathrm{T}$ alleles, respectively: 0.830 and 0.170 in Angus animals, 0.640 and 0.360 in Charolais animals, and 0.420 and 0.580 in Simmental animals. Carruthers et al. (2011) observed frequencies of 0.808 and 0.860 for the A allele, respectively, in two Angus populations, one with animals originating outside of Canada (international) and the other comprising Canadian bovines. No significant differences were observed between the allelic frequencies of the polymorphisms among the Nellore and crossbred groups, suggesting that the SNP is not exclusive to B. taurus or B. indicus.

Association analyses between the DQ499531.1:g.134A > T polymorphism of $P M C H$ and phenotypes showed no significant relationships for the five studied traits. In theory, the DQ499531.1:g.134A $>\mathrm{T}$ polymorphism could affect $\mathrm{BT}$ in cattle, which is potentially affected by alterations in the transcription rate of $P M C H$ and by the transcriptional repression of E4BP4 (Helgeson \& Schmutz, 2008). According to

Table 3. Allelic and genotypic frequencies of the DQ499531.1:g.134A > T polymorphism of $P M C H$ in various genetic groups and in the total animal sample ${ }^{(1)}$.

\begin{tabular}{lcccccc}
\hline Genetic group & \multicolumn{3}{c}{ Allelic frequency } & & \multicolumn{3}{c}{ Genotypic frequency } \\
\cline { 2 - 3 } & $\mathrm{A}$ & $\mathrm{T}$ & & $\mathrm{AA}$ & $\mathrm{AT}$ & $\mathrm{TT}$ \\
\hline Nellore (313) & $0.850 \mathrm{Aa}$ & $0.150 \mathrm{Bb}$ & & 0.821 & 0.058 & 0.12 \\
Angus $\times$ Nellore (67) & $0.985 \mathrm{Aa}$ & $0.015 \mathrm{Bb}$ & & 0.970 & 0.030 & 0.00 \\
Rubia Galega $\times$ Nellore (44) & $0.830 \mathrm{Aa}$ & $0.170 \mathrm{Bb}$ & & 0.659 & 0.341 & 0.00 \\
Canchim (41) & $0.915 \mathrm{Aa}$ & $0.085 \mathrm{Bb}$ & & 0.829 & 0.171 & 0.00 \\
Triple-cross Brangus (19) & $0.895 \mathrm{Aa}$ & $0.105 \mathrm{Bb}$ & & 0.789 & 0.211 & 0.00 \\
Triple-cross Brown Swiss (15) & $0.900 \mathrm{Aa}$ & $0.100 \mathrm{Bb}$ & 0.800 & 0.200 & 0.00 \\
\hline Total (499) & 0.896 & 0.104 & 0.812 & 0.168 & 0.02 \\
\hline
\end{tabular}

${ }^{(1)}$ Means followed by equal letters, uppercase between genetic groups and lowercase within genetic groups, do not differ by the comprehensive study of contingency tables (Curi \& Moraes, 1981), at 5\% probability. ${ }^{(2)}$ The number of animals in each genetic group is shown in parentheses. these authors, in the presence of glucocorticoids, the product of EABP4 binds to the $P M C H$ promoter and inhibits gene transcription. This occurs when the T allele is present without the A allele. These situations would result in lower PMHC (DQ499531.1:g.134A > T) and $R O R C$ expression in the presence of the $\mathrm{T}$ allele, affecting the deposition of subcutaneous fat. However, the results of the present study did not show a reduction in BT in the presence of the $\mathrm{T}$ allele. Helgeson \& Schmutz (2008) reported that B. taurus animals with the TT genotype have a tendency to present higher values for shear force than animals with the AA genotype.

For the DQ667048.1:g.3290G > T polymorphism of $R O R C$, the $\mathrm{G}$ and $\mathrm{T}$ alleles were both found (Table 4). A higher frequency of the $G$ allele was observed in the Nellore and Angus $\times$ Nellore groups. In the Rubia Galega $\times$ Nellore, Canchim, and triple-cross Brangus groups, there were no significant differences between the frequencies of the two alleles; and, for the triple-cross Brown Swiss group, the T allele was present with higher frequency. Furthermore, Nellore animals presented a higher frequency of the $G$ allele in comparison to the other groups. All three genotypes were observed in the evaluated genetic groups, with the exception of the Rubia Galega $\times$ Nellore and triple-cross Brown Swiss groups, which did not present individuals with GG genotypes.

In the present study, the allelic distributions found for the DQ667048.1:g.3290G > T polymorphism of RORC were 0.516 and 0.484 for the $\mathrm{G}$ and $\mathrm{T}$ alleles, respectively. Barendse et al. (2010), when evaluating the Angus and Shorthorn (B. taurus) bovine breeds,

Table 4. Allelic and genotypic frequencies of the DQ667048.1:g.3290G > T polymorphism of RORC in various genetic groups and in the total animal sample ${ }^{(1)}$.

\begin{tabular}{lcccccc}
\hline Genetic group & \multicolumn{3}{c}{ Allelic frequency } & & \multicolumn{3}{c}{ Genotypic frequency } \\
\cline { 2 - 3 } \cline { 5 - 7 } & G & T & & GG & GT & TT \\
\hline Nellore (313) & $0.797 \mathrm{Aa}$ & $0.203 \mathrm{Bb}$ & 0.639 & 0.316 & 0.045 \\
Angus $\times$ Nellore (67) & $0.627 \mathrm{Ba}$ & $0.373 \mathrm{Ab}$ & 0.299 & 0.657 & 0.045 \\
Rubia Galega $\times$ Nellore (44) & $0.409 \mathrm{Ba}$ & $0.591 \mathrm{Aa}$ & 0.000 & 0.818 & 0.182 \\
Canchim (41) & $0.476 \mathrm{Ba}$ & $0.524 \mathrm{Aa}$ & 0.171 & 0.610 & 0.220 \\
Triple-cross Brangus (19) & $0.421 \mathrm{Ba}$ & $0.579 \mathrm{Aa}$ & 0.105 & 0.632 & 0.263 \\
Triple-cross Brown Swiss (15) & $0.367 \mathrm{Bb}$ & $0.633 \mathrm{Aa}$ & 0.000 & 0.733 & 0.267 \\
\hline Total (499) & 0.516 & 0.484 & 0.202 & 0.628 & 0.170 \\
\hline
\end{tabular}

${ }^{(1)}$ Means followed by equal letters, uppercase between genetic groups and lowercase within genetic groups, do not differ by the comprehensive study of contingency tables (Curi \& Moraes, 1981), at 5\% probability. ${ }^{(2)}$ The number of animals in each genetic group is shown in parentheses. 
obtained frequencies of 0.433 for the $G$ allele and of 0.567 for $\mathrm{T}$, values similar to those of crossbred animals $(B$. indicus $\times$ B. taurus). Sevane et al. (2011) reported the frequencies of 0.300 and 0.700 for the $G$ and $\mathrm{T}$ alleles, respectively, in bovines of the Pasiega (B. taurus) breed. The trend observed in these studies, in which $B$. taurus animals show a higher T-allele frequency, are similar to those of the present study, in which the groups that comprised crossbred B. taurus animals had, on average, a higher frequency of the T allele than of the $\mathrm{G}$ allele.

The association analyses between the genotypes of the DQ667048.1:g.3290G > T polymorphism of $R O R C$ and the traits of interest showed no significant relationships between the polymorphism and carcass properties and meat quality.

Barendse et al. (2006) observed contrasting results, i.e., a positive association between the DQ667048.1:g.3290G > T SNP of RORC and the marbling score in the Angus and Shorthorn (B. taurus) breeds, in which the $\mathrm{T}$ allele proved favorable for the trait. Similarly, Sevane et al. (2011) found significant relationships in bovines of the Pasiega breed, in which the genotypes containing the $\mathrm{T}$ allele (GT and TT) presented significant association with increased back fat thickness. The disparity between these results and those obtained in the present study confirms that associations between molecular markers and traits of interest for specific populations are not immediately applicable to other ones, since the allele substitution effect of a polymorphism is due to widely known factors and parameters that are intrinsic to each population or breed in a given environment.

Even though more than one SNP has been described for the analyzed genes, in the present study only one polymorphism for each gene was investigated instead of haplotypes, because of the structure of the samples used, i.e., of the relatively small number of animals from each genetic group. The subdivision of each gene into multiple alleles (SNP haplotypes) rather than only into two (SNPs) would prevent reliable statistical analyses. Therefore, based on information from previous studies (Flisikowski et al., 2005; Barendse et al., 2006; Helgeson \& Schmutz, 2008), individual SNPs were chosen instead, considering the importance of their positions in the candidate genes or the positive results obtained in other association studies for economically important traits in cattle.
Due to the small number of animals used in relation to the large amount of genetic groups and environmental conditions, it is not possible to draw a definite conclusion about the association between the studied polymorphisms and traits of interest, especially regarding the IGF2/MboII $(\mathrm{G}>\mathrm{T})$ polymorphism of the $I G F 2$ gene.

\section{Conclusions}

1. The polymorphisms IGF2/MboII $(\mathrm{G}>\mathrm{T})$ of IGF2，DQ499531.1:g.134A $>\mathrm{T}$ of $P M H C$, and DQ667048.1:g.3290G $>$ T of RORC occur in Nellore (Bos indicus) cattle, and the frequencies of the alleles of $I G F 2$ and RORC differ between the Nellore and Nellore $\times$ Bos taurus groups.

2 . The analyzed single nucleotide polymorphisms (SNPs) of the IGF2, PMHC, and RORC genes are not associated with carcass and meat traits in the sample of animals studied.

\section{Acknowledgements}

To Fundação de Amparo à Pesquisa do Estado de São Paulo (Fapesp), for financial support; and to Coordenação de Aperfeiçoamento de Pessoal de Nível Superior (Capes), for fellowship.

\section{References}

ALLAIS, S.; JOURNAUX, L.; LEVÉZIEL, H.; PAYET-DUPRAT, N.; RAYNAUD, P.; HOCQUETTE, J.F.; LEPETIT, J.; ROUSSET, S.; DENOYELLE, C.; BERNARD-CAPEL, C.; RENAND, G. Effects of polymorphisms in the calpastatin and $\mu$-calpain genes on meat tenderness in 3 French beef breeds. Journal of Animal Science, v.89, p.1-11, 2011. DOI: 10.2527/jas.2010-3063.

BARENDSE, W.; BUNCH, R.J.; HARRISON, B.E.; THOMAS, M.B. The growth hormone $1 \mathrm{GH} 1: \mathrm{c} .457 \mathrm{C}>\mathrm{G}$ mutation is associated with intra-muscular and rump fat distribution in a large sample of Australian feedlot cattle. Animal Genetics, v.37, p.211-214, 2006. DOI: 10.1111/j.1365-2052.2006.01432.x.

BARENDSE, W.; BUNCH, R.J.; HARRISON, B.E. The effect of variation at the retinoic acid receptor-related orphan receptor $\mathrm{C}$ gene on intramuscular fat percent and marbling score in Australian cattle. Journal of Animal Science, v.88, p.47-51, 2010. DOI: 10.2527/jas.2009-2178.

BLIGH, E.G.; DYER, W.J. A rapid method of total lipid extraction and purification. Canadian Journal of Biochemistry and Physiology, v.37, p.911-917, 1959. DOI: 10.1139/o59-099. 
BONFERRONI, C.E. Teoria statistica delle classi e calcolo delle probabilità. Pubblicazioni del R Istituto Superiore di Scienze Economiche e Commerciali di Firenze, v.8, p.3-62, 1936.

CARRUTHERS, C.R.; PLANTE, Y.; SCHMUTZ, S.M. Comparison of Angus cattle populations using gene variants and microsatellites. Canadian Journal of Animal Science, v.91, p.81-85, 2011. DOI: 10.4141/CJAS10058.

CASAS, E.; WHITE, S.N.; RILEY, D.G.; SMITH T.P.L.; BRENNEMAN, R.A.; OLSON, T.A.; JOHNSON, D.D.; COLEMAN, S.W.; BENNETT, G.L.; CHASE JR., C.C. Assessment of single nucleotide polymorphisms in genes residing on chromosomes 14 and 29 for association with carcass composition traits in Bos indicus cattle. Journal of Animal Science, v.83, p.13-19, 2005.

CONEXÃO DELTA G. Conexão Delta G: associativismo. genética e lucro. Disponível em: <http://www.beefpoint.com.br/ cadeia-produtivismo-genetica-e-lucro-slides-e-artigo-63544/>. Acesso em: 6 jan. 2016.

CULLER, R.D.; PARRISH JR., F.C.; SMITH, G.C.; CROSS, H.R. Relationship of myofibril fragmentation index to certain chemical, physical and sensory characteristics of bovine longissimus muscle. Journal of Food Science, v.43, p.1177-1180, 1978. DOI: 10.1111/ j.1365-2621.1978.tb15263.x.

CURI, P.R.; MORAES, R.V. Associação, homogeneidade e contrastes entre proporções em tabelas contendo distribuições multinomiais. Ciência e Cultura, v.33, p.712-722, 1981.

CURI, R.A.; CHARDULO, L.A.L.; MASON, M.C.; ARRIGONI, M.D.B.; SILVEIRA, A.C.; OLIVEIRA, H.N. de. Effect of single nucleotide polymorphisms of CAPN1 and CAST genes on meat traits in Nellore beef cattle (Bos indicus) and in their crosses with Bos taurus. Animal Genetics, v.40, p.456-462, 2009. DOI: 10.1111/j.1365-2052.2009.01859.x.

FLISIKOWSKI, K.; MAJ, A.; ZWIERZCHOESKI, L.; ADAMOWICZ, T.; SWITONSKI, M.; HIENDLEDER, S.; PAREEK, C. Nucleotide sequence and variation of $I G F 2$ gene exon 6 in Bos taurus and Bos indicus cattle. Animal Biotechnology, v.16, p.203-208, 2005. DOI: 10.1080/10495390500278060.

GREEN, M.R.; SAMBROOCK, J. Molecular cloning: a laboratory manual. $4^{\text {th }}$ ed. New York: Cold Spring Harbor Laboratory Press, 2012. 2028p.

HAYES, B.; GODDARD, M. Genome-wide association and genomic selection in animal breeding. Genome, v.53, p.876-883, 2010. DOI: 10.1139/G10-076.

HELGESON, S.C.; SCHMUTZ, S.M. Genetic variation in the pro-melanin-concentrating hormone gene affects carcass traits in Bos taurus cattle. Animal Genetics, v.39, p.310-315, 2008. DOI: 10.1111/j.1365-2052.2008.01717.x.

HIROSE, T.; SMITH, R.J.; JETTEN, A.M. ROR-gamma, the third member of ROR/RZR orphan receptor subfamily that is highly expressed in skeletal-muscle. Biochemical and Biophysical Research Communications, v.205, p.1976-1983, 1994. DOI: 10.1006/bbrc.1994.2902.

ITO, M.; GOMORI, A.; ISHIHARA, A.; ODA, Z.; MASHIKO, S.; MATSUSHITA, H.; YUMOTO, M.; ITO, M.; SANO, H.;
TOKITA, S.; MORIYA, M.; IWAASA, H.; KANATANI, A. Characterization of $\mathrm{MCH}$-mediated obesity in mice. American Journal of Physiology - Endocrinology and Metabolism, v.284, p.E940-945, 2003. DOI: 10.1152/ajpendo.00529.2002.

KANEDA, M.; LIN, B.Z.; SASAZAKI, S.; OYAMA, K.; MANNEN, H. Allele frequencies of gene polymorphisms related to economic traits in Bos taurus and Bos indicus cattle breeds. Animal Science Journal, v.82, p.717-721, 2011. DOI: 10.1111/j.1 740-0929.2011.00910.x.

LUDTKE, C.B.; CIOCCA, J.R.P.; DANDIN, T.; BARBALHO, P.C.; VILELA, J.A.; FERRARINI, C. Abate humanitário de bovinos. Rio de Janeiro: WSPA, 147p. 2012.

LUDWIG, D.S.; TRITOS, N.A.; MASTAITIS, J.W.; KULKARNI, R.; KOKKOTOU, E.; ELMQUIST, J.; LOWELL, B.; FLIER, J.S.; MARATOS-FLIER, E. Melanin-concentrating hormone overexpression in transgenic mice leads to obesity and insulin resistance. Journal of Clinical Investigation, v.107, p.379-386, 2001. DOI: 10.1172/JCI10660.

MAEDA, M.; MURAYAMA, N.; ISHII, H.; URYU, N.; OTA, M.; TSUJ, K.; INOKO, H. A simple and rapid method for HLA-DQA1 genotyping by digestion of PCR-amplified DNA with allele specific restriction endonucleases. Tissue Antigens, v.34, p.290-298, 1989. DOI: 10.1111/j.1399-0039.1989.tb01745.x.

NEZER, C.; MOREAU, L.; BROUWERS, B.; COPPIETERS, W.; DETILLEUX, J.; HANSET, R.; KARIM, L.; KWASZ, A.; LEROY, P.; GEORGES, M. An imprinted QTL with major effect on muscle mass and fat deposition maps to the IGF2 locus in pigs. Nature Genetics, v.21, p.155-156, 1999. DOI: 10.1038/5935.

SCHMUTZ, S.; GOODALL, J. Improving production characteristics of cattle. Int. C12Q1/68. WO2005007881. 2005.

SEVANE, N.; DUNNER, S.; CELORIO, S.; SAÑUDO, B.; GONZÁLEZ, A.; GARCÍA, J.A.; ARGÜELLO, S. de; BARQUÍN, F.; CRESPO, M.J.; CHOMÓN, N.; CALDERÓN, L.A.; CAÑÓN, J. Aptitud productiva de la raza bovina Pasiega inferida de genes asociados con caracteres productivos. Archivos de Zootecnia, v.60, p.413-416, 2011. DOI: 10.4321/S0004-05922011000300024.

SHERMAN, E.L.; NKRUMAH, J.D.; MURDOCH, B.M.; LI, C.; WANG, Z.; FU, A.; MOORE, S.S. Polymorphisms and haplotypes in the bovine neuropeptide $\mathrm{Y}$, growth hormone receptor, ghrelin, insulin-like growth factor 2, and uncoupling proteins 2 and 3 genes and their associations with measures of growth, performance, feed efficiency, and carcass merit in beef cattle. Journal of Animal Science, v.86, p.1-16, 2008. DOI: 10.2527/jas.2006-799.

SILVEIRA, A.C.; MARTINS, C.L.; ARRIGONI, M.D.B. Produção do novilho superprecoce. In: SIMPÓSIO SOBRE BOVINOCUltura DE CORTE, 5., 2004, Piracicaba. Pecuária de corte intensiva nos trópicos: anais. Piracicaba: FEALQ, 2004. p.227-241.

UNITED STATES DEPARTMENT OF AGRICULTURE. United States standards for grades of feeder cattle. Washington: Usda, Agricultural Marketing Service, Livestock and Seed Program, 2000 .

WEIR, B.S. Genetic data analysis II: methods for discrete population genetic data. Sunderlang: Sinauer Associates, 1996. $376 \mathrm{p}$. 
WHEELER, T.L.; KOOHMARAIE, M.; SHACKELFORD, S.D. Standardized Warner-Bratzler shear force procedures for meat tenderness measurement. Clay Center: USDA, 1995.

ZHU, M.; ZHAO, S. Candidate gene identification approach: progress and challenges. International Journal of Biological Sciences, v.3, p.420-427, 2007. DOI: 10.7150/ijbs.3.420.
ZWIERZCHOWSKI，L.; SIADKOWSKA，E.; OPRZĄDEK, J.; FLISIKOWSKI, K.; DYMNICKI, E. An association of C/T polymorphism in exon 2 of the bovine insulin-like growth factor 2 gene with meat production traits in Polish Holstein-Friesian cattle. Czech Journal of Animal Science, v.55, p.227-233, 2010 .

Received on October 1, 2015 and accepted on January 18, 2016 